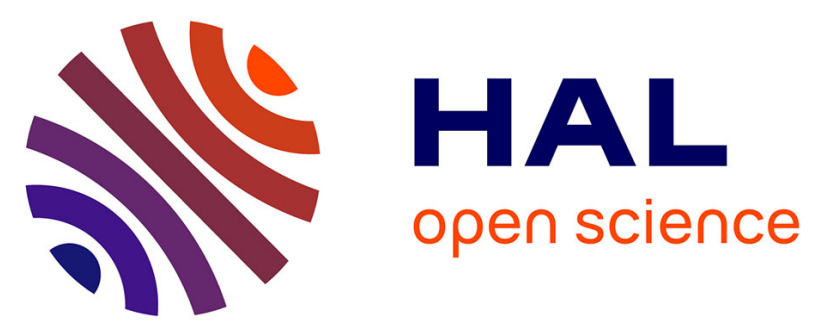

\title{
Studies on plant cell toxicity of luminescent silica nanoparticles (Cs2[Mo6Br14]@SiO2) and its constitutive components
}

Francisco Cabello-Hurtado, Maria Dolorès Lozano-Baena, Chrystelle Neaime, Agnès Burel, Sylvie Jeanne, Pascal Pellen-Mussi, Stéphane Cordier, Fabien

Grasset

\section{To cite this version:}

Francisco Cabello-Hurtado, Maria Dolorès Lozano-Baena, Chrystelle Neaime, Agnès Burel, Sylvie Jeanne, et al.. Studies on plant cell toxicity of luminescent silica nanoparticles (Cs2[Mo6Br14]@SiO2) and its constitutive components. Journal of Nanoparticle Research, 2016, 18 (3), pp.69. 10.1007/s11051-016-3381-6 . hal-01341580

\section{HAL Id: hal-01341580}

\author{
https://hal-univ-rennes1.archives-ouvertes.fr/hal-01341580
}

Submitted on 10 Sep 2020

HAL is a multi-disciplinary open access archive for the deposit and dissemination of scientific research documents, whether they are published or not. The documents may come from teaching and research institutions in France or abroad, or from public or private research centers.
L'archive ouverte pluridisciplinaire HAL, est destinée au dépôt et à la diffusion de documents scientifiques de niveau recherche, publiés ou non, émanant des établissements d'enseignement et de recherche français ou étrangers, des laboratoires publics ou privés. 


\section{Studies on plant cell toxicity of luminescent silica nanoparticles $\left(\mathrm{Cs}_{2}\left[\mathrm{Mog}_{6} \mathrm{Br}_{14}\right] @ \mathrm{SiO}_{2}\right)$ and its constitutive components}

Francisco Cabello-Hurtado $^{a} *$, María Dolores Lozano-Baena ${ }^{a}$, Chrystelle Neaime ${ }^{b}$, Agnès Burel ${ }^{c}$, Sylvie Jeanne ${ }^{b}$, Pascal Pellen-Mussi ${ }^{b}$, Stéphane Cordier ${ }^{b}$, Fabien Grasset $^{b, d}$

${ }^{a}$ UMR UR1-CNRS 6553 ECOBIO, Mechanisms at the Origin of Biodiversity Team, University of

Rennes 1, 263 av. du Général Leclerc, 35042 Rennes, France

${ }^{\mathrm{b}}$ UMR UR1-CNRS 6226 Institut des Sciences Chimiques de Rennes, Solid State Chemistry and

Materials Group, University of Rennes 1, 263 av. du Général Leclerc, 35042 Rennes, France

${ }^{\mathrm{c}}$ Electronic Microscopy Department, University of Rennes 1, 2 av. du Professeur Léon-Bernard, Campus de Villejean, 35043 Rennes, France

${ }^{d}$ CNRS-Saint Gobain, UMI 3629, Laboratory for Innovative Key Materials and Structures-Link, National Institute of Material Science (NIMS), GREEN/MANA Room 512, 1-1 Namiki, 305-0044 Tsukuba, Japan

* Corresponding author: e-mail: francisco.cabello@univ-rennes1.fr; phone: +33223235022; fax: $+33223235026$

\section{Acknowledgment}

This work was supported by the French National Research Agency (Project CLUSTOP 2011 BS0801301). Authors thank Marie Thérèse Lavault for technical assistance (MRic, UR 1), Juan B. Arellano for kindly providing Arabidopsis cells (IRNASA-CSIC), and Vincent Dorcet for nanoparticle TEM microcraphs (Plateforme THEMIS, UR1). 


\section{Abstract}

As part of the risk evaluation before potential applications of nanomaterials, phytotoxicity of newly designed multifunctional silica nanoparticles $\left(\mathrm{CMB} @ \mathrm{SiO}_{2}\right.$, average diameter of $\left.47 \mathrm{~nm}\right)$ and their components, i.e. molybdenum octahedral cluster bromide units $(\mathrm{CMB}, 1 \mathrm{~nm})$ and $\mathrm{SiO}_{2}$ nanoparticles $\left(\mathrm{nSiO}_{2}, 29 \mathrm{~nm}\right)$, has been studied using photosynthetic Arabidopsis thaliana cell suspension cultures. CMB clusters presented toxic effects on plant cells, inhibiting cell growth and negatively affecting cell viability and photosynthetic efficiency. Nevertheless, we showed that neither $\mathrm{nSiO}_{2}$ nor $\mathrm{CMB} @ \mathrm{SiO}_{2}$ have any significant effect on cell growth and viability or photosynthetic efficiency. At least part of the harmful impact of CMB clusters could be ascribed to their capacity to generate an oxidative stress since lipid peroxidation greatly increased after CMB exposure, which was not the case for $\mathrm{nSiO}_{2}$ or $\mathrm{CMB} @ \mathrm{SiO}_{2}$ treatments. Exposure of cells to $\mathrm{CMB}$ clusters also lead to the induction of several enzymatic antioxidant activities (i.e. superoxide dismutase, guaiacol peroxidase, glutathione peroxidase, glutathione reductase, and glutathione Stransferase activities) compared to control and the other treatments. Finally, using electron microscopy, we showed that Arabidopsis cells internalize CMB clusters and both silica nanoparticles, the latter through, most likely, endocytosis-like pathway as nanoparticles were mainly found incorporated into vesicles.

\section{Keywords}

8 


\section{Introduction}

Manufactured nanoparticles (NPs) (one dimension $<100 \mathrm{~nm}$ ) are being increasingly produced for a wide range of applications and are present in hundreds of nanotechnology products (Buzea et al. 2007). However, they are also bringing new toxic effects on human and environmental health (Buzea et al. 2007; Colvin 2003). Among nanomaterials, the use of functional synthetic amorphous silicon dioxide or silica nanoparticles $\left(\mathrm{nSiO}_{2}\right)$ in information technology, biotechnology and medicine is becoming increasingly accepted for a variety of therapeutic, diagnostic and imaging applications (Selvan et al. 2010). The challenge for nanotechnologies at this point is to elaborate non-toxic and aging resistant phosphorescent silica nanoparticles emitting in the near infrared region (NIR). For this purpose, new functional silica nanoparticles incorporating luminescent molybdenum hexanuclear cluster bromide units $\left(\mathrm{Cs}_{2} \mathrm{Mo}_{6} \mathrm{Br}_{14}\right.$, noted $\mathrm{CMB}$, as the cluster precursor) inside monodispersed and size-controlled silica nanoparticles (noted $\mathrm{CMB} @ \mathrm{SiO}_{2}$ ) have been recently developed in our group (Aubert et al. 2013). Besides, Mo6-based clusters are already involved in several patents for applications in biotechnology as contrast agents (Long et al. 1998), oxygen sensors (Baker et al. 2010) and in display technologies (Cordier et al. 2015).

Silica nanoparticles are used as matrices because of their versatility and their relative biocompatibility (Fruijtier-Pölloth 2012). However, this point of $\mathrm{nSiO}_{2}$ safety is controversial, and different studies reported toxic effects in some cells or organisms like humans (Brown et al. 2015; Guarnieri et al. 2014; Napierska et al. 2010), other animals (Debnath et al. 2011; Lee et al. 2009; Parveen et al. 2014), algae (van Hoecke et al. 2011) or bacteria (Adams et al. 2006). Concerning higher plants, most of the studies reported null or positive effects (Le et al. 2014; Lee et al. 2010; Lin et al. 2004; Nair et al. 2011; Siddiqui and Al-Whaibi 2014; Slomberg and Schoenfisch 2012), $\mathrm{nSiO}_{2}$ toxicity being only observed at very high concentrations (Le et al. 2014; Lee et al. 2010). The toxic mechanisms of $\mathrm{nSiO}_{2}$ exposure remain far from clear, but in some cases $\mathrm{nSiO}_{2}$ toxic effects were related to interactions with cellular surfaces (membrane or cuticle), oxidative stress and/or 
genotoxicity (Adams et al. 2006; Brown et al. 2015; Debnath et al. 2011; Fruijtier-Pölloth 2012; Napierska et al. 2010; Parveen et al. 2014).

$\mathrm{SiO}_{2}$ nanoparticles are a common nanomaterial which is used (either or not in admixture with other elements) for a variety of applications in the medical (biomedicine, biosensor, disease labeling) and technological (food processing, ceramics synthesis, industrial and household applications) fields, but also in the environmental (wastewater treatment, water purification, environmental remediation) and agriculture fields. In agriculture, silica nanoparticles are used in different formulations, mainly as carriers in chemical delivery, or in uptake and translocation of nutrient elements, and as active ingredients against insect pests (Gogos et al. 2012), thereby fostering their dispersion in the environment. In this context, luminescent properties of $\mathrm{CMB} @ \mathrm{SiO}_{2}$ nanoparticles are not without interest for biotechnological uses that could also be applied to plants, or to be combined with silica nanoparticles intended for agronomical uses. From these current and potential uses of silica nanoparticles, it is obvious that their potential to harm the environmental is a relevant issue. Plants, as important environmental components and sinks in terrestrial and aquatic ecosystems, are essential living organisms for testing ecological effects of nanoparticles. Hence, it is of great importance to study the impact of new functional silica nanoparticles on plant cells, and to anticipate new potential risks derived from their accumulation into plants and their subsequent fate within food chains. In earlier studies on the impact of $\mathrm{CMB} @ \mathrm{SiO}_{2}$ nanoparticles and of $\mathrm{CMB}$ clusters in plant growth (Aubert et al. 2012; 2013), we showed that silica nanoparticles containing clusters have no effect on plant growth, whereas $\mathrm{CMB}$ clusters penetrated into roots and negatively impacted growth. In these studies, roots were always much more affected than aerial parts, certainly due to the root direct contact with clusters and the very low translocation of clusters into aerial part. The latter makes it difficult to analyze the direct impact of these nanomaterials on photosynthetic cells in these root-treated systems. Indeed, the absence of adverse effects reported in most works evaluating silica nanoparticle phytotoxicity could be partially linked to low or no occurrence of silica nanoparticles in photosynthetic cells, rather than the lack of inherent hazards. At this respect 
in particular, the use of plant cell cultures provides a way for in vitro exposing photosynthetic cells directly to the action of nanoparticles. In fact this model system can mimic, as regards with plant cell interaction with nanoparticles, the situation that could be found in photosynthetic cells of aerial parts of plants exposed to $\mathrm{CMB} @ \mathrm{SiO}_{2}, \mathrm{nSiO}_{2}$ or $\mathrm{CMB}$ in a chronic way, where a higher accumulation of nanoparticles in leaves can be achieved after a long-time exposure.

In order to go further in $\mathrm{CMB} @ \mathrm{SiO}_{2}, \mathrm{nSiO}_{2}$ and $\mathrm{CMB}$ toxicological research, and with the aim of exploring the impact of weak doses on photosynthetic cells, we have chosen light-grown Arabidopsis thaliana cell suspension cultures (ACSC) as a valuable cellular system in which to investigate oxidative damage and cell response. ACSC join uniformity, homogeneity, repeatability, decoupling of cellular processes from development and slow systemic effects between cells (Menges et al. 2003), to the convenience of application of nanomaterial treatments. Here, we present studies on biochemical and oxidative stress factors on A. thaliana cells under exposure to functional $\mathrm{CMB} @ \mathrm{SiO}_{2}$ nanoparticles and their components, $\mathrm{nSiO}_{2}$ nanoparticles and $\mathrm{CMB}$ clusters. The in vitro cytotoxicity of these nanomaterials was examined by investigating their influence on cell growth and viability, photosynthesis, lipid peroxidation, and antioxidant enzyme activities (i.e. superoxide dismutase (SOD), guaiacol peroxidase (POD), glutathione peroxidase (GPX), glutathione reductase (GR), and glutathione S-transferase (GST) activities). Finally, the fate of nanoparticles in the medium and their penetration into plant cells was detected by transmission electron microscopy (TEM).

\section{Materials and Methods}

Chemicals, cluster units, and silica nanoparticles 
Polyoxyethylene (4) lauryl ether (Brij30) and tetraethoxysilane (TEOS, 99.00\%) were purchased from Sigma-Aldrich. Ammonia (28 wt \% in water) and n-heptane $(99.00 \%)$ were purchased from VWR. Ethanol (99.80\%) was purchased from Fluka. $\mathrm{Cs}_{2} \mathrm{Mo}_{6} \mathrm{Br}_{14}$ was used as the precursor of $\left[\mathrm{Mo}_{6} \mathrm{Br}_{14}\right]^{2-}$ cluster units.

Hexamolybdenum cluster units are nanometric building blocks (1 nm) constituted of a Mo6 octahedral cluster bonded to 8 inner $\mathrm{Br}^{\mathrm{i}}(\mathrm{i}=$ inner) ligands capping the faces of the octahedron and 6 apical $\mathrm{Br}^{\mathrm{a}}\left(\mathrm{a}=\right.$ apical) ligands in terminal positions. The negative charge of the $\left[\mathrm{Mo}_{6} \mathrm{Br}_{14}\right]^{2-}$ cluster unit is counter balanced by two $\mathrm{Cs}^{+}$cations. In solid state, the cluster units co-crystallize with the cations to form a cluster compound denoted $\mathrm{Cs}_{2} \mathrm{Mo}_{6} \mathrm{Br}_{14}$. The $\mathrm{Cs}_{2} \mathrm{Mo}_{6} \mathrm{Br}_{14}$ cluster compound can be dispersed as nanosized entities in ethanolic solution (Grasset et al. 2008).

All the silica nanoparticles have been prepared using a water-in-oil (W/O) microemulsion process developed by our group since the earlier 2000 (Aubert et al. 2010; Grasset et al. 2002). In this work, the complex water phase was prepared by dissolving the $\mathrm{Cs}_{2}\left[\mathrm{Mo}_{6} \mathrm{Br}_{14}\right]$ cluster compound in a mixture of ethanol and distilled water (1:1 volume ratio). The concentration of the cluster sol was $0.02 \mathrm{M}$. For pure $\mathrm{nSiO}_{2}$, the complex water phase was free of cluster. Finally, the nanoparticles were collected and washed by several centrifugation cycles to remove surfactant molecules before to be dispersed in purified water at concentration around $15 \mathrm{~g} \mathrm{~L}^{-1}$. The average hydrodynamic size of the silica nanoparticles in water solution was estimated by dynamic light scattering (Supplementary Fig. 1) using a Malvern Zetasizer Nano ZS apparatus. All the samples were studied by TEM (Supplementary Fig. 2) using a microscope JEOL $2100 \mathrm{LaB}_{6}$ at $200 \mathrm{kV}$ or JEOL JEM1400 microscope operating at $120 \mathrm{kV}$. Samples for TEM analysis were prepared by placing a drop of the diluted solution in mesh copper grids, allowing the solvent in the grid to evaporate at room temperature.

\section{ACSC growth conditions and nanomaterial treatments}


The Arabidopsis thaliana (ecotype Col-0) cell suspension cultures were kindly provided by the Institute of Natural Resources and Agronomy from Salamanca (IRNASA-CSIC, Spain). ACSC were maintained at $24^{\circ} \mathrm{C}$ under sterile conditions in $200 \mathrm{~mL}$ of liquid growth medium (Axelos et al. 1992; Jouanneau et al. 1967) by agitation at $120 \mathrm{rpm}$ and under continuous illumination $\left(50 \mu \mathrm{E} \mathrm{m} \mathrm{m}^{-2}\right.$ $\mathrm{s}^{-1}$ ) in an incubator shaker (Innova 42R, NBS). For nanoparticle toxicity tests, we applied luminescent silica nanoparticles $\left(\mathrm{CMB} @ \mathrm{SiO}_{2}\right)$ and their constituents (i.e. $\mathrm{CMB}$ clusters and $\left.\mathrm{nSiO}_{2}\right)$ into 9 days-old ACSC (cell density of 150-200 $\mathrm{mg} \mathrm{mL}^{-1}$ ). For these studies, three different concentrations of $\mathrm{CMB} @ \mathrm{SiO}_{2}$ and $\mathrm{nSiO}_{2}\left(1,10\right.$ and $\left.100 \mathrm{mg} \mathrm{L}{ }^{-1}\right)$, and of CMB clusters $(1,7.5$ and $60 \mathrm{mg} \mathrm{L}^{-1}$ ) were tested. Treated ACSC were incubated for up to three days under normal growth conditions, and sample aliquots collected at 3,24 and $72 \mathrm{~h}$. Collected samples were centrifuged at $4000 \mathrm{rpm}$ for $5 \mathrm{~min}$, the supernatant was removed, and the cell pellet was weighed, frozen in liquid nitrogen and finally stored at $-80^{\circ} \mathrm{C}$ until further analysis.

For stock solutions to be used for nanoparticle toxicity tests, $\mathrm{CMB} @ \mathrm{SiO}_{2}$ and $\mathrm{nSiO}_{2}$ were suspended in water at $5 \mathrm{~g} \mathrm{~L}^{-1}$, and $\mathrm{CMB}$ in $50 \%$ ethanol at $60 \mathrm{~g} \mathrm{~L}^{-1} . \mathrm{CMB}_{\mathrm{S}} \mathrm{SiO}_{2}$ used here are composed of $7.5 \%$ clusters and $92.5 \% \mathrm{SiO}_{2}$ (Aubert et al. 2013). Thus, the intermediate CMB concentration $\left(7.5 \mathrm{mg} \mathrm{L}^{-1}\right)$ used for treatments corresponds to the cluster content associated to the intermediate concentration of $\mathrm{CMB} @ \mathrm{SiO}_{2}$ nanoparticles $\left(100 \mathrm{mg} \mathrm{L}{ }^{-1}\right)$. From this intermediate CMB concentration, we have set the lowest $\mathrm{CMB}$ concentration at $1 \mathrm{mg} / \mathrm{L}$, which correspond (rounded to the nearest unit) to the cluster content present in $10 \mathrm{mg} / \mathrm{L}$ of $\mathrm{CMB} @ \mathrm{SiO}_{2}$, and the highest $\mathrm{CMB}$ concentration at $60 \mathrm{mg} / \mathrm{L}$ (in order not to exceed $0.05 \%$ of ethanol in cell culture medium). As control, we used ACSC without added nanomaterial but containing the equivalent volume of the corresponding solvent or medium as used for the nanomaterial tested.

\section{Cell viability assay}


179 Cell mitochondria and metabolic activities were measured by the MTT (3-(4,5-dimethylthiazol-2180 yl)-2,5-diphenyl tetrazolium bromide) test following manufacturer's indications (Cell growth 181 determination kit CGD-1, Sigma-Aldrich). Cell density was adjusted to $25 \mathrm{mg} \mathrm{mL} \mathrm{m}^{-1}$ at the 182 beginning of the treatment, and cell dilution for MTT assay was the same for all the samples. 183 Relative cell viability was expressed as the percentage of control untreated cells and calculated by 184 [Absorbance $570 \mathrm{~nm}-$ Absorbance $690 \mathrm{~nm}]_{\text {test }} /\left[\mathrm{A}_{570}-\mathrm{A}_{690}\right]_{\text {control }} \times 100$.

Pigment analysis

The chlorophyll and carotenoid contents were determined spectrophotometrically following Lichtenthaler and Wellburn (1983) equations. Collected cells were lyophilised (Christ ALPHA 12LDplus) and pigments extracted from $20 \mathrm{mg}$ dry weight (DW) by overnight pure acetone extraction at $4{ }^{\circ} \mathrm{C}$. The absorbance was quantified at 470,645 and $663 \mathrm{~nm}$ using a micro plate spectrophotometer (SAFAS, Xenius).

Modulated chlorophyll fluorescence measurements were made in ACSC (previously dark adapted 197 for $30 \mathrm{~min}$ ) with a PAM-210 chlorophyll fluorometer (Heinz Walz). Maximum quantum yield of 198 photosynthesis was estimated by the $F_{v} / F_{m}$ ratio from dark-adapted ACSC, where $F_{v}$ is calculated 199 subtracting the minimal fluorescence $\left(F_{o}\right)$ to the maximal fluorescence $\left(F_{m}\right)$. 
The level of lipid peroxidation was determined by measuring the amount of TBARS (thiobarbituric acid reactant species) produced by the thiobarbituric acid (TBA) reaction, according to the corrected TBA method as described by Hodges et al. (1999) adapted to 96-well plates.

Antioxidant enzyme extraction and activity assays

Enzyme extracts correspond to supernatants obtained after homogenizing A. thaliana cells in sodium phosphate buffer $(50 \mathrm{mM}, \mathrm{pH} 7.5)$ with Na-EDTA $(1 \mathrm{mM})$, polyvinyl-pyrrolidone $(5 \%$ w/v), sodium ascorbate (5 mM) and Protease Inhibitor Cocktail (0.5\% v/v, Sigma-P9599) at a ratio of $1 \mathrm{~mL}$ per $20 \mathrm{mg}$ DW. Protein contents were determined according to Bradford (Bradford 1976), using bovine serum albumin as the standard protein. Enzyme extracts were frozen in liquid nitrogen and kept at $-80^{\circ} \mathrm{C}$ until their use for enzymatic assays. All enzyme assays were adapted to 96 -well plates (final reaction volume of $300 \mu \mathrm{L}$ ).

SOD activity was determined based on the inhibition of the reduction of nitro-blue tetrazolium (NBT) into formazan in the presence of riboflavin as described by Giannopolitis and Ries (1977). Formazan formation was determined measuring the absorbance at $560 \mathrm{~nm}$ after 10 min of incubation under white light at $25^{\circ} \mathrm{C}$. The reaction mixture consisted of $10 \mu \mathrm{L}$ of enzyme extract, potassium phosphate buffer $(50 \mathrm{mM}, \mathrm{pH} 7.8)$, EDTA $(0.1 \mathrm{mM})$, NBT $(75 \mu \mathrm{M})$, methionine $(13$ $\mathrm{mM})$ and riboflavin $(2 \mu \mathrm{M})$.

POD activity was measured by the method of Srivastava and van Huystee (1977) with a reaction mixture consisting of $5 \mu \mathrm{L}$ of enzyme extract, potassium phosphate buffer (100 mM, pH 6.5), $\mathrm{H}_{2} \mathrm{O}_{2}$ $(0.05 \% \mathrm{v} / \mathrm{v})$ and guaiacol $(15 \mathrm{mM})$. The enzymatic activity was determined from the maximum rate of tetragaiacol formation by monitoring the increase in absorbance at $470 \mathrm{~nm}$ ( $\varepsilon_{\text {Tetragaiacol }}=26.6$ $\left.\mathrm{mM}^{-1} \mathrm{~cm}^{-1}\right)$.

GPX activity was measured by a coupled assay system in which oxidation of GSH was coupled to NADPH oxidation catalyzed by glutathione reductase according to the method of Floh and 
229 Günzler (1984). The reaction mixture consisted of $5 \mu \mathrm{L}$ of enzyme extract, potassium phosphate 230 buffer (100 mM, pH 7.0), cumene hydroperoxide (0.5 mM), GSH (4 mM), NADPH (0.2 mM) and 2310.5 units of yeast glutathione reductase. The enzymatic activity was determined at $25^{\circ} \mathrm{C}$ from the 232 maximum rate of NADPH oxidation by monitoring the decrease in absorbance at $340 \mathrm{~nm}\left(\varepsilon_{\mathrm{NADPH}}=\right.$ $\left.6.22 \mathrm{mM}^{-1} \mathrm{~cm}^{-1}\right)$.

GR activity was measured according to the method of Carlberg and Mannervik (1985), following the oxidized glutathione (GSSG)-dependent oxidation of NADPH. The assay mixture consisted of $10 \mu \mathrm{L}$ of enzyme extract, HEPES buffer $(50 \mathrm{mM}, \mathrm{pH} 8.0)$, EDTA $(0.5 \mathrm{mM})$, GSSG $(0.5 \mathrm{mM})$ and NADPH $(0.25 \mathrm{mM})$. The enzymatic activity was determined at $25^{\circ} \mathrm{C}$ from the maximum rate of NADPH oxidation by monitoring the decrease in absorbance at $340 \mathrm{~nm}\left(\varepsilon_{\mathrm{NADPH}}=6.22 \mathrm{mM}^{-1} \mathrm{~cm}^{-1}\right)$.

GST activity was measured by the method of Habig and Jacoby (1981) using CDNB (1-chloro-2, 4-dinitrobenzene) as the substrate. The assay mixture consisted of $5 \mu \mathrm{L}$ of enzyme extract, potassium phosphate buffer (100 mM, pH 7.4), GSH (1 mM) and CNDB (1 mM). The enzymatic activity was determined at $25^{\circ} \mathrm{C}$ from the maximum rate of $\mathrm{GSH} / \mathrm{CNDB}$ conjugate formation by monitoring its absorbance at $340 \mathrm{~nm}\left(\varepsilon_{\mathrm{CNDB}}=9.6 \mathrm{mM}^{-1} \mathrm{~cm}^{-1}\right)$.

All enzymatic activities but SOD were expressed as nkat $\mathrm{mg}^{-1}$ protein. SOD activity was expressed as $\mathrm{U} \mathrm{mg}^{-1}$ protein, $\mathrm{U}$ (a unit) being the amount of enzyme causing $50 \%$ inhibition of the NBT reduction observed in the absence of enzyme.

ACSC TEM analysis

TEM samples were prepared following standard procedures. Roughly, collected cell samples were centrifuged at $1700 \mathrm{~g}$ for $5 \mathrm{~min}$, the supernatants were removed, and the cell pellets were washed once with cacodylate buffer, chemically prefixed in $2.5 \%(\mathrm{v} / \mathrm{v})$ glutaraldehyde for $1.5 \mathrm{~h}$, washed 3 times in sodium cacodylate buffer $(0.2 \mathrm{M}, \mathrm{pH} 7.1)$, then post fixed in $0.5 \%(\mathrm{v} / \mathrm{v})$ osmium tetroxide for $1 \mathrm{~h}$, and washed 3 times in sodium cacodylate buffer $(0.2 \mathrm{M}, \mathrm{pH} 7.1)$. The samples were then 
255 included in low melting agar (4\%) and dehydrated in several ethanol baths with increasing 256 concentrations. The specimens were embedded in an Araldite/Epon epoxy resin from which 257 ultrathin sections (thickness: $90 \mathrm{~nm}$ ) were cut using an ultramicrotome (LEICA UC7) and directly 258 deposited on copper grids. The grids were visualized in a JEOL 1400 microscope operated at 120 $259 \mathrm{kv}$ and using a Gatan $2 \mathrm{kX} 2 \mathrm{k}$ Orius camera. Image analysis on the silica nanoparticles and clusters 260 was carried out on 35 TEM images. The processing of the image files was performed on more than 261500 particles using standard ImageJ analysis software (http://rsbweb.nih.gov/ij/). Particle size is 262 presented as mean \pm standard deviation (SD).

264 Statistical analysis

Statistical analyses were performed with $\mathrm{R}$ software version 3.2.1 (http://www.r-project.org/). Normality and homoscedasticity were confirmed with Shapiro and Bartlett tests for each assay. The results are presented as mean \pm standard error of the mean (SEM) of three independent experiments.

Differences between means were evaluated for significance by Student's t-test for pairwise comparisons, and by one-way analysis of variance (ANOVA) followed of Tukey's test for multiple comparisons. Statistical significance was accepted when $p<0.05$.

\section{Results}

Particle characterization

The hydrodynamic diameter of the two types of silica nanoparticles was found to be comprised between 40-60 $\mathrm{nm}$ from the dynamic light scattering data in aqueous dispersion at $\mathrm{pH}=7.4$, which indicates that the nanoparticles are not or slightly aggregated in the solution. The result obtained for 
$\mathrm{CMB} @ \mathrm{SiO}_{2}$ is represented in Supplementary Fig. 1 as example. These results are in the same range as the size observed by scanning electron microscopy (not shown) and TEM. The TEM images of the $\mathrm{nSiO}_{2}$ and $\mathrm{CMB} @ \mathrm{SiO}_{2}$ are as shown in Supplementary Fig. 2. Diameter sizes of 'as produced' $\mathrm{CMB} @ \mathrm{SiO}_{2}$ and $\mathrm{nSiO}_{2}$ obtained from the TEM image are of $47 \pm 3$ and $29 \pm 2 \mathrm{~nm}$, respectively.

Impacts of nanomaterials on cell growth and cell viability

In our conditions, ACSC grew with a doubling time of about 2.1 days and had a cell density around $200 \mathrm{mg} \mathrm{mL}^{-1}$ at the beginning of the stationary phase (between 9 to 11 days after subculture). No changes in cell growth or viability were observed $3 \mathrm{~h}$ after exposure, regardless of nanomaterial (Fig. 1a-c). However, depending on the type of nanomaterial, significant changes in cell growth were detected during longer treatment periods. Thus, while ACSC exposed to $\mathrm{CMB} @ \mathrm{SiO}_{2}$ or $\mathrm{nSiO}_{2}$ at concentrations up to $100 \mathrm{mg} \mathrm{L}^{-1}$ are capable to continue normal growth up to $72 \mathrm{~h}$ after treatment (Fig. 1a, b), $60 \mathrm{mg} \mathrm{L}^{-1}$ CMB significantly impacted ACSC growth (18.5 and $21.3 \%$ of growth inhibition after 24 and $72 \mathrm{~h}$ of treatment, respectively) (Fig. 1c).

On the other hand, Arabidopsis cell viability was assessed by the MTT assay (Fig. 1d-f). In agreement with the impact of nanomaterials on cell growth, only CMB clusters at their highest used concentration had significant cytotoxic effects, provoking a 45.6 and $27.7 \%$ decrease of cell viability after 24 and $72 \mathrm{~h}$ of exposure respectively (Fig. 1f).

\section{Changes in chloroplast pigment content and photosynthetic efficiency}

The impact of nanomaterials on chloroplasts was evaluated through the analyses of chlorophyll and carotenoid contents, and PSII photochemical efficiency. Light-grown ACSC used for nanomaterial treatments were pale green and contained about $240 \mu \mathrm{g}$ chlorophyll and $85 \mu \mathrm{g}$ carotenoid per gram DW. Chlorophyll content remained unchanged during treatment in light-grown control, and in 
$\mathrm{CMB} @ \mathrm{SiO}_{2}$ and $\mathrm{nSiO}_{2}$ treated ACSC, whereas ACSC treated with 60 ppm CMB experienced a 13 and $21 \%$ decline in chlorophyll content after 24 and $72 \mathrm{~h}$ of treatment respectively (Fig. 2a-c). Concerning carotenoid content, we roughly observed a similar behavior as for chlorophyll, CMB clusters being the only nanomaterial to have a significant impact on it (Fig. 2d-f). Finally, it should also be noted that the chlorophyll a/b and chlorophyll/carotenoid mass ratios in control ACSC at the beginning of the treatment were approximately 3.7 and 2.7 respectively, and that they were not affected by any of the nanomaterials (data not shown).

The maximum quantum yield of photosynthesis is generally influenced by stress situations, and is usually estimated by the ratio Fv/Fm. The maximum quantum yield of photosynthesis in lightgrown ACSC reached a level of around 0.45-0.55 in 9-days-old ACSC used for nanomaterial treatments, and changed little during treatment time course.CMB@ $\mathrm{SiO}_{2}$ treatments did not affected $\mathrm{F}_{\mathrm{v}} / \mathrm{F}_{\mathrm{m}}$ values (Fig. 2g, h) but CMB significantly did (Fig. 2i) through 24-72 hours of treatment at all the tested concentrations.

\section{Oxidative impact and enzymatic antioxidant response}

We studied the mechanisms of cytotoxicity caused by nanomaterials with respect to oxidative stress through the oxidative impact on lipids (lipid peroxidation) and the antioxidant response (antioxidant enzymatic activities). The oxidative degradation of lipids by reactive oxygen species (ROS), called lipid peroxidation, results in the formation of highly reactive and unstable lipid peroxides which decomposed into TBARS, including malondialdehyde (MDA). Thus, TBARS level give a convenient estimation of the relative lipid peroxide content. The TBARS content of control 9-dayold ACSC was $\approx 14-16$ nmol MDA equivalents $\mathrm{g}^{-1}$. After nanomaterial exposure, a significant increase of lipid peroxidation was only observed for $60 \mathrm{mg} \mathrm{L}^{-1}$ CMB-treated cells (Fig. 3). In this case, lipid peroxidation increased with time treatment, being of $119 \%$ after $24 \mathrm{~h}$ and $143 \%$ after $72 \mathrm{~h}$ of treatment. 
In order to understand the adaptability and to determine the nature of the antioxidant responses

of A. thaliana cells to the different nanomaterials, we analyzed the activities of five antioxidant enzymes, i.e. superoxide dismutase (SOD; EC 1.15.1.1), guaiacol peroxidase (POD; EC 1.11.1.7), glutathione peroxidase (GPX; EC 1.11.1.9), glutathione reductase (GR; EC 1.8.1.7) and glutathione S-transferase (GST; EC 2.5.1.18), in ACSC treated for 3, 24 and 72 hours with investigated nanoparticles at different concentrations. The only nanomaterial affecting SOD (Fig. 4a-c), POD (Fig. 4d-f) and GR (Fig. 4g-i) activities were CMB clusters. Thus, A. thaliana cells undergoing 60 ppm CMB treatment showed, relative to control, a 50\% transitory increase in SOD activity after 24 h, and a marked increase in POD (2 and 1.9 times) and GR (1.6 and 1.5 times) activities after 24 and $72 \mathrm{~h}$ of treatment. On the other hand, GPX activity (Fig. $4 \mathrm{j}-1$ ) was increased by all the nanomaterials tested, but with different induction patterns. Thus, while $60 \mathrm{ppm}$ CMB clusters induced GPX after 24 and 72 h of treatment, CMB@ $\mathrm{SiO}_{2}$ and $\mathrm{nSiO}_{2}$ slightly induced GPX after 3 $\mathrm{h}$, and $\mathrm{nSiO}_{2}$ was able to provoke a second wave of inductions in a concentration-dependent way after 72 h. Finally, concerning GST activity (Fig. 4m-o), all the nanomaterials at the different concentrations were able to early induce GST ( $3 \mathrm{~h}$ after treatment). The highest increase of GST activity was obtained after $\mathrm{nSiO}_{2}$ treatment, but only 60 ppm CMB maintained GST induction over time.

Nanoparticle interaction with plant cells as examined by TEM

In culture medium ('as exposed' state), CMB clusters showed tendency to aggregate forming particles of a diameter around $83 \pm 14 \mathrm{~nm}$, which agglomerate to form different shape branched structures under the micrometer range (Fig. 5a). On the other hand, 'as exposed' CMB@ $\mathrm{SiO}_{2}$ and $\mathrm{nSiO}_{2}$ stayed non aggregated and spherical in shape with diameters, as measured from TEM micrographs, of $44 \pm 4$ and $27 \pm 2 \mathrm{~nm}$, respectively (Fig. 5b, c). These nanoparticle sizes were not 
significantly different from 'as produced' sizes measured from TEM micrographs (Supplementary Fig. 2).

In addition, Arabidopsis cells were also observed by TEM to determine if the different nanomaterials entered the plant cells. In the case of CMB treated cells (Fig. 5a, d), they display altered cell wall ultrastructure, presenting a loosely structured cell wall (reduced electron density) but more than twice as thick compared with that of control cells (Supplementary Fig. 3). Cluster aggregates seem to be present inside this loose cell wall and central vacuole, but are not observed inside vesicles. Furthermore, we cannot rule out the presence of individual nanometric clusters which, as already mentioned, are not detectable when they are at their synthesis size $(1 \mathrm{~nm}$ diameter) due to resolution limit of the TEM available for this work. In contrast, $\mathrm{CMB} @ \mathrm{SiO}_{2}($ Fig. 5b, e) and $\mathrm{nSiO}_{2}$ (Fig. 5c, f) were observed inside plant cells and seemed to conserve their 'as produced' and 'as exposed' sizes. Furthermore, $\mathrm{CMB} @ \mathrm{SiO}_{2}$ and $\mathrm{nSiO}_{2}$ were observed inside vesicles (Fig. 5d, e), pointing endocytosis as a mechanism of cell uptake for these nanoparticles.

\section{Discussion}

Luminescent functional silica nanoparticles based on Mo6 clusters possess a huge potential for application in the field of nanobiotechnology or nanophotonics (Cordier et al. 2015). For a reasonable and responsible development of their use, potential toxic effects must be deeply studied. Here, the cytotoxicity of low/medium doses of functional silica nanoparticles and their components was investigated under in vitro conditions using photosynthetic A. thaliana cell cultures. CMB clusters at $60 \mathrm{ppm}$ concentration negatively impacted cells, significantly reducing cell growth and viability (Fig. 1) in agreement with their reported negative impact on plant root growth (Aubert et al. 2012). In the case of silica nanoparticles, none negative effect were observed on ACSC growth or viability after neither $\mathrm{CMB} @ \mathrm{SiO}_{2}$ nor 'empty' $\mathrm{nSiO}_{2}$ treatments at any tested concentration. 
Slomberg and Schoenfisch (2012) already showed that $\mathrm{nSiO}_{2}$ did not caused toxic effects on $A$. thaliana plants up to $1 \mathrm{~g} \mathrm{~L}^{-1}$, but in this case $\mathrm{nSiO}_{2}$ contact with photosynthetic cells was negligible since they reported minimal upward translocation to foliage.

The impact of $\mathrm{CMB} @ \mathrm{SiO}_{2}, \mathrm{nSiO}_{2}$ and $\mathrm{CMB}$ on chloroplast functioning has never been evaluated. We have first showed that although photosynthesis is not necessary for ACSC survival, the photosynthetic electron transport chain of thylakoid membranes in light-grown ACSC is active (Fig. 2). Thus, we measured quantum yield of photosynthesis $\left(\mathrm{F}_{\mathrm{v}} / \mathrm{F}_{\mathrm{m}}\right)$ values around 0.6 for control ACSC, which is in agreement with those from the literature for A. thaliana cell cultures (GonzálezPérez et al. 2011) and indicates that A. thaliana cell cultures produce functional chloroplasts, even if this ratio is lower than the 0.8 determined for green leaves (Zhang et al. 2008). In addition, the levels of chlorophylls (240 $\left.\mu \mathrm{g} \mathrm{g}^{-1} \mathrm{DW}\right)$ and carotenoids ( $\left.85 \mu \mathrm{g} \mathrm{g}^{-1} \mathrm{DW}\right)$ were in perfect agreement with those described in the literature for A. thaliana cell cultures (González-Pérez et al. 2011; Doyle et al. 2010) and represent, respectively, about $2.5 \%$ and $5.5 \%$ of the levels described in leaf tissues (Zhang et al. 2008; Doyle et al. 2010). Furthermore, while the chlorophyll $a / b$ ratio (around 3.7) was close to those for mature chloroplasts of A. thaliana leaves (around 3.3), the chlorophyll/carotenoid mass ratio (around 2.7) was much lower than in A. thaliana leaves (around 6.4) (Zhang et al. 2008). Photosynthetic apparatus parameters such as pigment content (chlorophylls and carotenoids), pigment ratios, and photosynthesis yield are good indicators for stress detection and tolerance (Doyle et al. 2010; Zhang et al. 2008). In our work, only CMB clusters significantly impacted these parameters, decreasing chlorophyll and carotenoid contents as well as $F_{v} / F_{m}$ values, but without affecting $\mathrm{Chl} a / b$ or chlorophyll/carotenoid ratios. It is worth to be noted that a significant decreased in maximum quantum yield of photosynthesis was observed for CMB doses as low as $1 \mathrm{ppm}$. This photosynthetic unbalance can generate excess energy, which is extremely harmful and dangerous for plant cell metabolism, notably because it provokes the accumulation of ROS which may lead to damages in the thylakoid membranes and protein modulation (Ruban 2015). In the light of the foregoing, photosynthetic apparatus seems to be more sensitive to CMB 
under light conditions than cell growth or viability. This can be attributed to the fact that light enhances ROS production by clusters, precisely ${ }^{1} \mathrm{O}_{2}$ (Aubert et al. 2013), and that this could synergically interact with ROS production in different organelles, notably those associated to photosynthetic light-driven process: ${ }^{1} \mathrm{O}_{2}$ in PSII, superoxide radical $\left(\mathrm{O}_{2}{ }^{-}\right)$in PSI, and hydrogen peroxide $\left(\mathrm{H}_{2} \mathrm{O}_{2}\right)$ in the chloroplast stroma (Gill and Tuteja 2010).

We have shown in previous work that ${ }^{1} \mathrm{O}_{2}$ production involving $\mathrm{CMB}$ clusters can be prevented, to some extent, by the encapsulation of the cluster units in silica nanoparticles (Aubert et al. 2013). However, the capacity of CMB to provoke an oxidative stress in cells, and the impact of silica encapsulation on this, has never been studied. It is well known that the generation of ROS as natural by-products during cell metabolism is enhanced in the different plant cell compartments after the exposure of plants to environmental stresses, provoking subsequent damage in cell biomolecules and metabolism. We chose to follow MDA production (through TBARS quantification) because MDA is a product of the peroxidation of unsaturated fatty acids and it has been used as an indicator of free radical damage to cell membranes under stress conditions (Gill and Tuteja 2010). Under nanomaterial treatment, the TBARS content was found to be increased only after CMB cluster exposure. This could be explained on the basis of the above mentioned ${ }^{1} \mathrm{O}_{2}$ production by CMB under light conditions, as it has been shown that ${ }^{1} \mathrm{O}_{2}$ mediate lipid peroxidation (Triantaphylidès et al. 2008), and matches with previous studies showing that the $\mathrm{CMB} @ \mathrm{SiO}_{2}$ nanoparticles are particularly stable and do not liberate clusters (Aubert et al. 2013). Furthermore, even if oxygen has been shown to still have access to some cluster units from $\mathrm{CMB} @ \mathrm{SiO}_{2}$ and produce ${ }^{1} \mathrm{O}_{2}$, we showed here that silica encapsulation of CMB clusters prevents ${ }^{1} \mathrm{O}_{2}$ production at levels able to provoke lipid peroxidation in A. thaliana cells.

To protect themselves against ROS production and uncontrolled lipid peroxidation, plant cells possess and induce an array of antioxidant defense systems (Gill and Tuteja 2010). We analyzed the activities of an array of antioxidant enzymes (SOD, POD, GPX, GR and GST) under nanomaterial treatment conditions. Within these activities, SOD, which catalyze disproportionation of $\mathrm{O}_{2} .^{-}$into 
$\mathrm{H}_{2} \mathrm{O}_{2}$ and $\mathrm{O}_{2}$, belong to the first line of defense. The $\mathrm{H}_{2} \mathrm{O}_{2}$ produced in the cell, by SOD or other processes, may be scavenged by catalases and peroxidases, the latter including POD and GPX. Additionally, GPX may also reduce lipid hydroperoxides. For their part, GST catalyze the conjugation of electrophilic substrates to reduced glutathione, and can also function as glutathione peroxidases. Finally, the glutathione oxidized in cells is regenerated by GR utilizing NADPH. The increment in the activity of SOD after $24 \mathrm{~h}$ of exposure to CMB, and the higher increase of POD and GR activities after CMB treatment at 24 and $72 \mathrm{~h}$, suggested their role in the defense system against $\mathrm{CMB}$ induced oxidative stress, either by the removal of ROS and of toxic products of organic peroxidation. Moreover, the induction of POD, which are mainly considered extracellular proteins, in interplay with apoplastic SOD could participate in initial oxidative burst and signal transduction pathways (Francoz et al. 2015) as well as cell wall loosening (Minibayeva et al. 2015). Interestingly, the latter have been observed in CMB treated cells (Fig. 5 and Supplementary Fig. 3). It should also be pointed out that, in agreement with the absence of physiological (cell growth and viability, pigments, and quantum yield of photosynthesis) and oxidative (lipid peroxidation) impacts, $\mathrm{CMB} @ \mathrm{SiO}_{2}$ and $\mathrm{nSiO}_{2}$ treatments did not have a marked impact on antioxidant activities, exception done of the induction of GR activity by $\mathrm{nSiO}_{2}$ after a long exposure period $(72 \mathrm{~h})$, and the early induction of GST activity by both silica nanoparticles.

It is well-known that the properties of nanomaterials can change from the form in which they are synthesized to the form to which biological test systems are exposed, and that these potential changes in size, shape or aggregation, among other, could influence toxicity. In previous studies we showed that the CMB clusters and cluster aggregates can be found in a wide range of sizes depending on the dispersing medium, and that their concentration-dependent toxicity depends on their aggregation state (Aubert et al. 2012). Consequently, here we analyzed using TEM the different nanomaterials in the exposure medium and in intimate contact with living cells. Even if silica nanoparticles can have tendency to agglomerate and aggregate in high ionic strength medium like growth medium (Guarnieri et al. 2014), we observed that hydrophilic CMB@ $\mathrm{SiO}_{2}$ and $\mathrm{nSiO}_{2}$ 
do not aggregate in plant cell growth medium and presented similar size and shape that 'as produced' (Fig. 5b, c). It should be mentioned that due to the resolution limit of the TEM available for this work, it is not possible to see the nanosized metal cluster inside the $\mathrm{CMB} @ \mathrm{SiO}_{2}$ silica nanoparticles. For this particular point, the reader should see Grasset et al. (2008). In contrast, as expected from our previous work, $1 \mathrm{~nm} \mathrm{CMB}$ clusters aggregate forming structures with "sphericlike" shapes that further agglomerates into ramified structures of different shapes and sizes (Fig. 5a). Actually, even if cluster units are nanosized entities, they are hydrolyzed in presence of water and co-precipitate with water molecules to form the crystalline compound $\left[\left(\mathrm{Mo}_{6} \mathrm{Br}_{8}{ }^{\mathrm{i}}\right)(\mathrm{OH})_{4}^{\mathrm{a}}{ }_{4}(\mathrm{H} 2 \mathrm{O})^{\mathrm{a}}{ }_{2}\right] \cdot 12 \mathrm{H}_{2} \mathrm{O}$. However, it is worth to be noted that the sizes of aggregates (up to one hundred nanometers) in present work conditions were smaller than in previous ones (from several hundred nanometers to few micrometers), and that shapes are also different to the disc-like aggregates previously observed. The TEM grid preparation could be one reason to explain this difference.

The uptake and bioaccumulation of nanoparticles by plants is crucial in many respects, such as environmental issues, food-chain transfer, biotechnological applications and interaction with cell organelles or toxicity. There have been only a few studies examining silica nanoparticle uptake by plants. These studies reported different degrees of nanoparticle root uptake and internalization onto plant cells, and more rarely their upward translocation into shoots (Le et al. 2014; Nair et al. 2011; Slomberg and Schoenfisch 2012; Torney et al. 2007; Vivero-Escoto et al. 2012). In our system, we observed that both silica nanoparticles intimately interact with the cell wall, and seem to be internalized into Arabidopsis cells by endocytosis since they were mainly found encapsulated in vesicles (Fig. 5e, f). Indeed, recent studies have shown that plant cells are able to accomplish endocytosis for the internalization of molecules from the extracellular environment in a process resembling mammalian cell endocytosis (Fan et al. 2015). In contrast, CMB clusters were observed forming aggregates inside cell walls and vacuoles, but not inside vesicles, suggesting that clusters 
mainly penetrate by passive diffusion as nanosized entities. We already described this situation in root cells of $A$. thaliana seedlings treated with CMB (Aubert et al. 2012).

A final consideration concerns the potential participation of ion release in the toxicity of the evaluated nanomaterials. The observed perturbation of cell growth and metabolism in response to Mo-based clusters cannot be ascribed to the eventual release of metal ions as we already showed that only the apical Br ligands (6 atoms) and the Cs counter cations (2 atoms) were liberated from clusters in culture medium, but no Mo was released in the solution as ionic species. At the highest concentration of $\mathrm{CMB}$ clusters $\left(60 \mathrm{mg} \mathrm{L}^{-1}=0.0306 \mathrm{mM}\right)$ used in the present study, levels of $\mathrm{Cs}^{+}$ and $\mathrm{Br}^{-}$ions liberated would be 0.0612 and $0.1836 \mathrm{mM}$ respectively, which is far down toxic concentrations for these ions (Aubert et al. 2012).

\section{Conclusion}

ACSC showed to be an appropriate screening system to assess plant biological responses to nanomaterials, allowing proper interactions of the biological system with the evaluated nanomaterials. We showed in this study that Mo6-based clusters, even at low doses, present a significant toxicity for plant cells, negatively affecting growth, viability and photosynthesis, and increasing oxidative impact, which provoked stimulation of antioxidant enzymatic activities. Based on the results presented here, it is also concluded that the encapsulation of the clusters into silica, which showed to be biologically compatible in our conditions, protected the plant cells by avoiding direct contact of harmful clusters with cellular structures and the generation of oxidative stress. Thus, deleterious impacts were not observed after $\mathrm{CMB} @ \mathrm{SiO}_{2}$ nanoparticle exposure, and $\mathrm{nSiO}_{2}$ nanoparticles neither showed cytotoxic effects, despite intimate contact with cells and their internalization. 


\section{$514 \quad$ References}

515

Adams LK, Lyon DY, Alvarez PJJ (2006) Comparative eco-toxicity of nanoscale $\mathrm{TiO}_{2}, \mathrm{SiO}_{2}$, and ZnO water suspensions. Water Res 40:3527-3532. doi:10.1016/j.watres.2006.08.004

Aubert T, Burel A, Esnault M-A, Cordier S, Grasset F, Cabello-Hurtado F (2012) Root uptake and phytotoxicity of nanosized molybdenum octahedral clusters. J Hazard Mater 219-220:111-118. doi:10.1016/j.jhazmat.2012.03.058

Aubert T, Cabello-Hurtado F, Esnault M-A, Neaime C, Lebret-Chauvel D, Jeanne S, Pellen P, Roiland C, Le Polles L, Saito N, Kimoto K, Haneda H, Ohashi N, Grasset F, Cordier S (2013) Extended investigations on luminescent $\mathrm{Cs}_{2}\left[\mathrm{Mo}_{6} \mathrm{Br}_{14}\right] @ \mathrm{SiO}_{2}$ nanoparticles: physico-structural characterizations and toxicity studies. J Phys Chem C 117:20154-20163. doi:10.1021/jp405836q

Aubert T, Grasset F, Mornet S, Duguet E, Cador O, Cordier S, Molard Y, Demange V, Mortier M, Haneda H (2010) Functional silica nanoparticles synthesized by water-in-oil microemulsion processes. J Colloid Interface Sci 341:201-208. doi:10.1016/j.jcis.2009.09.064

Axelos M, Curie C, Mazzolini L, Bardet C, Lescure B (1992) A protocol for transient gene expression in Arabidopsis thaliana protoplasts isolated from cell suspension cultures. Plant Physiol Biochem 30:123-128.

Baker GL, Ghosh RN, Osborn DJ (2010) Sol-gel encapsulated hexanuclear clusters for oxygen sensing by optical techniques. U.S. Patent 7,858,380

Bradford MM (1976) A rapid and sensitive method for the quantitation of microgram quantities of protein utilizing the principle of protein-dye binding. Anal Biochem 72:248-54

Buzea C, Pacheco II, Robbie K (2007) Nanomaterials and nanoparticles: sources and toxicity. Biointerphases 2:MR17-MR71. doi:10.1116/1.2815690

Brown DM, Varet J, Johnston H, Chrystie A, Stone V (2015) Silica nanoparticles and biological 
dispersants: genotoxic effects on A549 lung epithelial cells. J Nanopart Res 17:1-16. doi:10.1007/s11051-015-3210-3

541 Carlberg I, Mannervik B (1985) Glutathione reductase. Methods Enzymol 113:484-490.

542 Colvin V-L (2003) The potential environmental impact of engineered nanomaterials. Nat Biotechnol 21:1166-1170. doi:10.1038/nbt875

Cordier S, Grasset F, Molard Y, Amela-Cortes M, Boukherroub R, Ravaine S, Mortier M, Ohashi N, Saito N, Haneda H (2015) Inorganic molybdenum octahedral nanoclusters, versatile functionnal building block for nanoarchitectonics. J Inorg Organomet Polym Mater 25:189204. doi:10.1007/s10904-014-0112-2

Debnath N, Das S, Chandra DSR, Bhattacharya SCh, Goswami A (2011) Entomotoxic effect of silica nanoparticles against Sitophilus oryzae (L.). J Pest Sci 84:99-105. doi:10.1007/s10340$010-0332-3$

Doyle SM, Diamond M, McCabe PF (2010) Chloroplast and reactive oxygen species involvement in apoptotic-like programmed cell death in Arabidopsis suspension cultures. J Exp Bot 61:473482. doi:10.1093/jxb/erp320

Fan L, Li R, Pan J, Ding Z, Lin J (2015) Endocytosis and its regulation in plants. Trends Plant Sci 20:388-397. doi:10.1016/j.tplants.2015.03.014

Floh L, Günzler WA (1984) Assays of glutathione peroxidase. Methods Enzymol 105:114-121

Francoz E, Ranocha P, Nguyen-Kim H, Jamet E, Burlat V, Dunand C (2015) Roles of cell wall

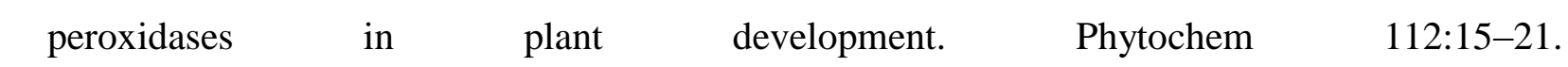
doi:10.1016/j.phytochem.2014.07.020

Fruijtier-Pölloth C (2012) The toxicological mode of action and the safety of synthetic amorphous silica-A nanostructured material. Toxicology 294:61-79. doi:10.1016/j.tox.2012.02.001

Giannopolitis CN, Ries SK (1977) Superoxide dismutase I. Occurrence in higher plants. Plant Physiol 59:309-314.

Gill SS, Tuteja N (2010) Reactive oxygen species and antioxidant machinery in abiotic stress 
566 Gogos A, Knauer K, Bucheli TD (2012) Nanomaterials in plant protection and fertilization: current 567 state, foreseen applications, and research priorities. J Agr Food Chem 60:9781-9792. doi:10.1021/jf302154y

González-Pérez S, Gutiérrez J, García-García F, Osuna D, Dopazo J, Lorenzo O, Revuelta JL, Arellano JB (2011) Early transcriptional defense responses in Arabidopsis cell suspension culture under high-light conditions. Plant Physiol 156:1439-1456. doi/10.1104/pp.111.177766

Guarnieri D, Malvindi MA, Belli V, Pompa PP, Netti P (2014) Effect of silica nanoparticles with variable size and surface functionalization on human endothelial cell viability and angiogenic activity. J Nanopart Res 16:1-14. doi:10.1007/s11051-013-2229-6

Grasset F, Dorson F, Cordier S, Molard Y, Perrin C, Marie AM, Sasaki T, Haneda H, Bando Y, Mortier M (2008) Water-in-oil microemulsion preparation and characterization of $\mathrm{Cs}_{2} \mathrm{Mo}_{6} \mathrm{X}_{14} @ \mathrm{SiO}_{2}$ phosphor nanoparticles based on transition metal clusters $(\mathrm{X}=\mathrm{Cl}, \mathrm{Br}$, and $\mathrm{I})$. Adv Mater 20:143-148. doi:10.1002/adma.200701686

Grasset F, Labhsetwar N, Li D, Park DC, Saito N, Haneda H, Cador O, Roisnel T, Mornet S, Duguet E, Portier J, Etourneau J (2002) Synthesis and magnetic characterization of zinc ferrite nanoparticles with different environments: powder, colloidal solution and zinc ferrite-silica core-shell nanoparticles. Langmuir 18:8209-8216. doi:10.1021/1a020322b

Habig WH, Jakoby WB (1981) Assays for differentiation of glutathione-S-transferases. Methods Enzymol 77:398-405

Hodges DM, DeLong JM, Forney CF, Prange RK (1999) Improving the thiobarbituric acidreactive-substances assay for estimating lipid peroxidation in plant tissues containing anthocyanin and other interfering compounds. Planta 207:604-611. doi: $10.1007 / \mathrm{s} 004250050524$

Jouanneau JP, Péaud-Lenoël C (1967) Growth and synthesis of proteins in cell suspensions of a kinetin dependent tobacco. Physiol Plant 20:834-850 
Le V, Rui Y, Gui X, Li X, Liu S, Han Y (2014) Uptake, transport, distribution and Bio-effects of $\mathrm{SiO}_{2}$ nanoparticles in Bt-transgenic cotton. J Nanobiotechnology 12:50. doi:10.1186/s12951014-0050-8

Lee CW, Mahendra S, Zodrow K, Li D, Tsai YC, Braam J, Alvarez PJ (2010) Developmental phytotoxicity of metal oxide nanoparticles to Arabidopsis thaliana. Environ Toxicol Chem 29:669-675. doi:10.1002/etc.58

Lee SW, Kim SM, Choi J (2009) Genotoxicity and ecotoxicity assays using the freshwater crustacean Daphnia magna and the larva of the aquatic midge Chironomus riparius to screen the ecological risks of nanoparticle exposure. Environ Toxicol Phar 28:86-91. doi:10.1016/j.etap.2009.03.001

Lichtenthaler HK, Wellburn AR (1983) Determination of total carotenoids and chlorophyll $a$ and $b$ of leaf extract in different solvents. Biochem Soc T 11:591-592

Lin BS, Diao SQ, Li CH, Fang LJ, Qiao SC, Yu M (2004) Effect of TMS (nanostructured silicon dioxide) on growth of Changbai larch seedlings. J For Res-CHN 15:138-140. doi: 10.1007/BF02856749

Long JR, Xheng X, Holm RH, Yu S-B, Droege M, Sanderson WA (1998) Contrast agents. U.S. Patent 5,804,161

Menges M, Hennig L, Gruissem W, Murray JAH (2003) Genome-wide gene expression in an Arabidopsis cell suspension. Plant Mol Biol 53:423-442. doi: 10.1023/B:PLAN.0000019059.56489.ca

Minibayeva F, Beckett RP, Ilse K (2015) Roles of apoplastic peroxidases in plant response to wounding. Phytochem 112:122-129. doi:10.1016/j.phytochem.2014.06.008

Nair R, Poulose A, Nagaoka Y, Yoshida Y, Maekawa T, Kumar DS (2011) Uptake of FITC labeled silica nanoparticles and quantum dots by rice seedlings: effects on seed germination and their potential as biolabels for plants. J Fluoresc 21:2057-2068. doi:10.1007/s 10895-011-0904-5

Napierska D, Thomassen LC, Lison D, Martens JA, Hoet PH (2010) The nanosilica hazard: another 
variable entity. Part Fibre Toxicol 7:39. doi:10.1186/1743-8977-7-39

Parveen A, Rizvi SHM, Mahdi F, Tripathi S, Ahmad I, Shukla RK, Khanna VK, Singh R, Patel DK, Mahdi AA (2014) Silica nanoparticles mediated neuronal cell death in corpus striatum of rat brain: implication of mitochondrial, endoplasmic reticulum and oxidative stress. J Nanopart Res 16:1-15. doi:10.1007/s11051-014-2664-z

Ruban AV (2015) Evolution under the sun: optimizing light harvesting in photosynthesis. J Exp Bot 66: 7-23. doi:10.1093/jxb/eru400

Selvan ST, Tan TT, Yi DK, Jana NR (2010) Functional and multifunctional nanoparticles for bioimaging and biosensing. Langmuir 26:11631-11641. doi:10.1021/la903512m

Siddiqui MH, Al-Whaibi MH (2014) Role of nano- $\mathrm{SiO}_{2}$ in germination of tomato (Lycopersicum esculentum seeds Mill.). Saudi J Biol Sci 21:13-17. doi:10.1016/j.sjbs.2013.04.005

Slomberg DL, Schoenfisch MH (2012) Silica nanoparticle phytotoxicity to Arabidopsis thaliana. Environ Sci Technol 46:10247-10254. doi:10.1021/es300949f

Srivastava OP, van Huystee RB (1977) IAA oxidase and polyphenol oxidase activities of peanut peroxidase isoenzymes. Phytochem 16:1527-1530

Torney F, Trewyn BG, Lin VS-Y, Wang K (2007) Mesoporous silica nanoparticles deliver DNA and chemicals into plants. Nat Nanotech 2:295-300. doi:10.1038/nnano.2007.108

Triantaphylidès C, Krischke M, Hoeberichts FA, Ksas B, Gresser G, Havaux M, van Breusegem F, Mueller MJ (2008) Singlet oxygen is the major reactive oxygen species involved in photooxidative damage to plants. Plant Physiol 148:960-968. doi:10.1104/pp.108.125690

van Hoecke K, de Schamphelaere KAC, Ramirez-Garcia S, van der Meeren P, Smagghe G, Janssen CR (2011) Influence of alumina coating on characteristics and effects of $\mathrm{SiO}_{2}$ nanoparticles in algal growth inhibition assays at various $\mathrm{pH}$ and organic matter contents. Environ Int 37:11181125. doi:10.1016/j.envint.2011.02.009 
641 Vivero-Escoto JL, Huxford-Phillips RC, Lin W (2012) Silica-based nanoprobes for biomedical 642 imaging and theranostic applications. Chem Soc Rev 41:2673-2685. 643 doi:10.1039/C2CS15229K

644 Zhang X, Wollenweber B, Jiang D, Liu F, Zhao J (2008) Water deficits and heat shock effects on 645 photosynthesis of a transgenic Arabidopsis thaliana constitutively expressing ABP9, a bZIP 646 transcription factor. J Exp Bot 59:839-848. doi:10.1093/jxb/erm364 
649 Fig. 1 A. thaliana cell biomass concentration ( $\mathrm{g}$ fresh weight $\left.\mathrm{mL}^{-1}\right)(\mathbf{a}-\mathbf{c})$ and cell viability $(\mathbf{d}-\mathbf{f})$. ACSC 650 were treated with $\mathrm{CMB} @ \mathrm{SiO}_{2}(\mathbf{a}, \mathbf{d}), \mathrm{nSiO}_{2}(\mathbf{b}, \mathbf{e})$ and $\mathrm{CMB}$ clusters $(\mathbf{c}, \mathbf{f})$ at different concentrations for 3, 65124 and 72 hours. Relative cell viability is expressed as percentage related to control at each time point. * 652 Significant differences between nanomaterial treatment and control $(p<0.05)$

653

654 Fig. 2 ACSC chlorophyll (a-c) and carotenoid (d-f) contents ( $\mu \mathrm{g} \mathrm{g}^{-1}$ dry weight), and PSII maximum 655 quantum yield $\left(\mathrm{F}_{\mathrm{v}} / \mathrm{F}_{\mathrm{m}}\right)(\mathbf{g}-\mathbf{i})$. ACSC were treated with $\mathrm{CMB} @ \mathrm{SiO}_{2}(\mathbf{a}, \mathbf{d}, \mathbf{g}), \mathrm{nSiO}_{2}(\mathbf{b}, \mathbf{e}, \mathbf{h})$ and $\mathrm{CMB}$ 656 clusters $(\mathbf{c}, \mathbf{f}, \mathbf{i})$ at different concentrations for 3, 24 and 72 hours. * Significant differences between 657 nanomaterial treatment and control $(p<0.05)$

658

659 Fig. 3 Level of lipid peroxidation in A. thaliana cells. ACSC were treated with $\mathrm{CMB}_{0} \mathrm{SiO}_{2}(\mathbf{a}), \mathrm{nSiO}_{2}(\mathbf{b})$ 660 and CMB clusters (c) at different concentrations for 3, 24 and 72 hours. TBARS content is expressed as 661 percentage related to control at each time point. * Significant differences between nanomaterial treatment 662 and control $(\mathrm{p}<0.05)$

663

664 Fig. 4 Antioxidant enzymatic activities in A. thaliana cells. ACSC were treated with $\mathrm{CMB} @ \mathrm{SiO}_{2}(\mathbf{a}, \mathbf{d}, \mathbf{g}, \mathbf{j}$, $665 \mathrm{M}), \mathrm{nSiO}_{2}(\mathbf{b}, \mathbf{e}, \mathbf{h}, \mathbf{k}, \mathbf{n})$ and $\mathrm{CMB}$ clusters $(\mathbf{c}, \mathbf{f}, \mathbf{i}, \mathbf{l}, \mathbf{o})$ at different concentrations for 3, 24 and 72 hours. 666 Different letters above bars indicate statistical significance $(\mathrm{p}<0.05)$ at each time point 667

668 Fig. 5 TEM images of $A$. thaliana cells in culture medium after 72 hours of treatment with $60 \mathrm{mg} \mathrm{L}^{-1} \mathrm{CMB}^{-1}$

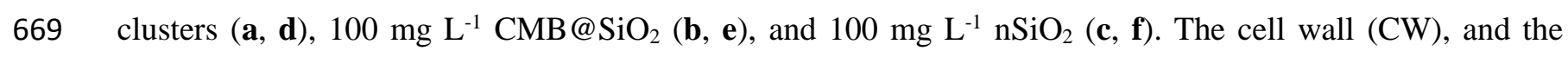
670 nanomaterials outside (black arrows) and inside cells, cell wall or vesicles (white arrows) are shown 


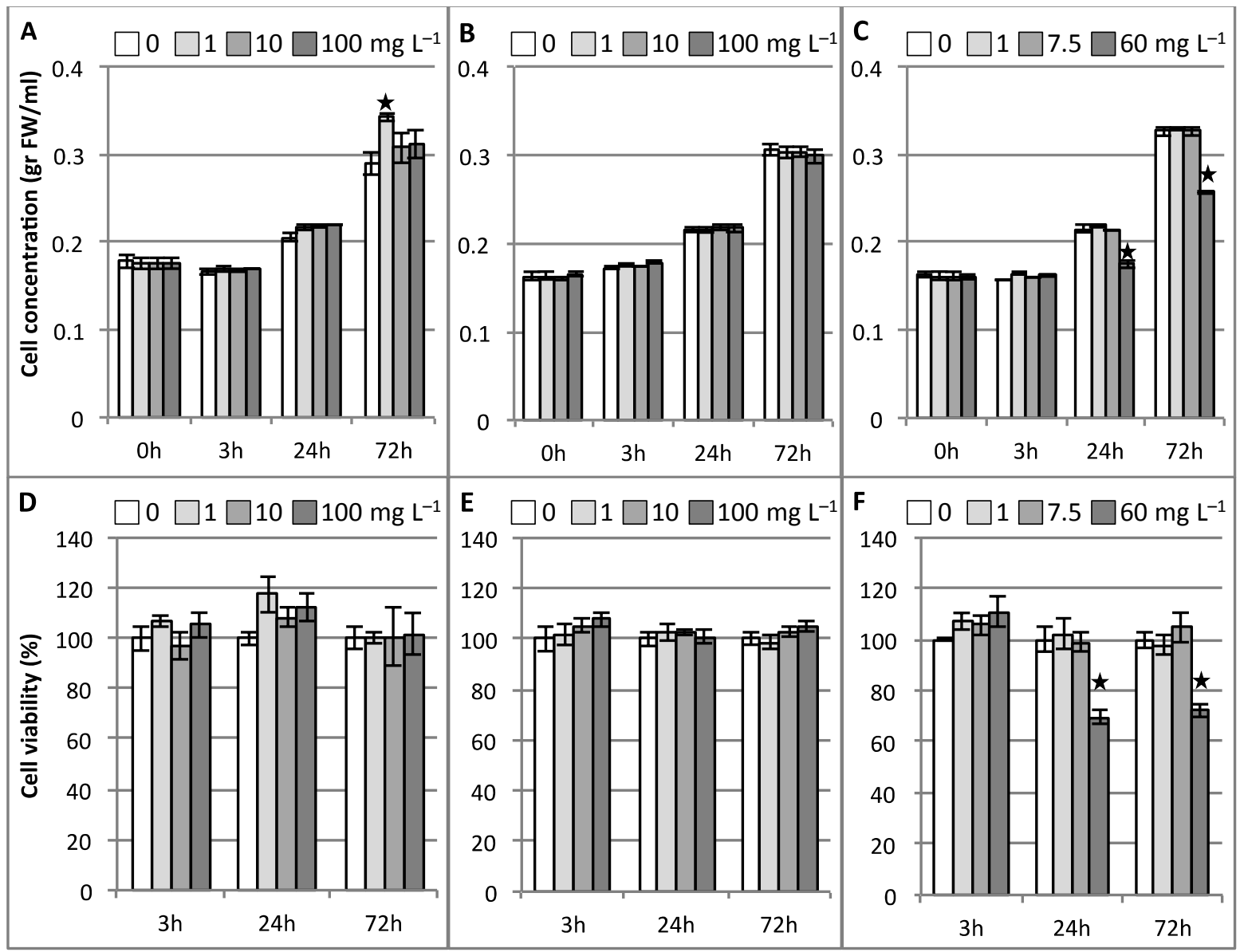

Fig. 1 

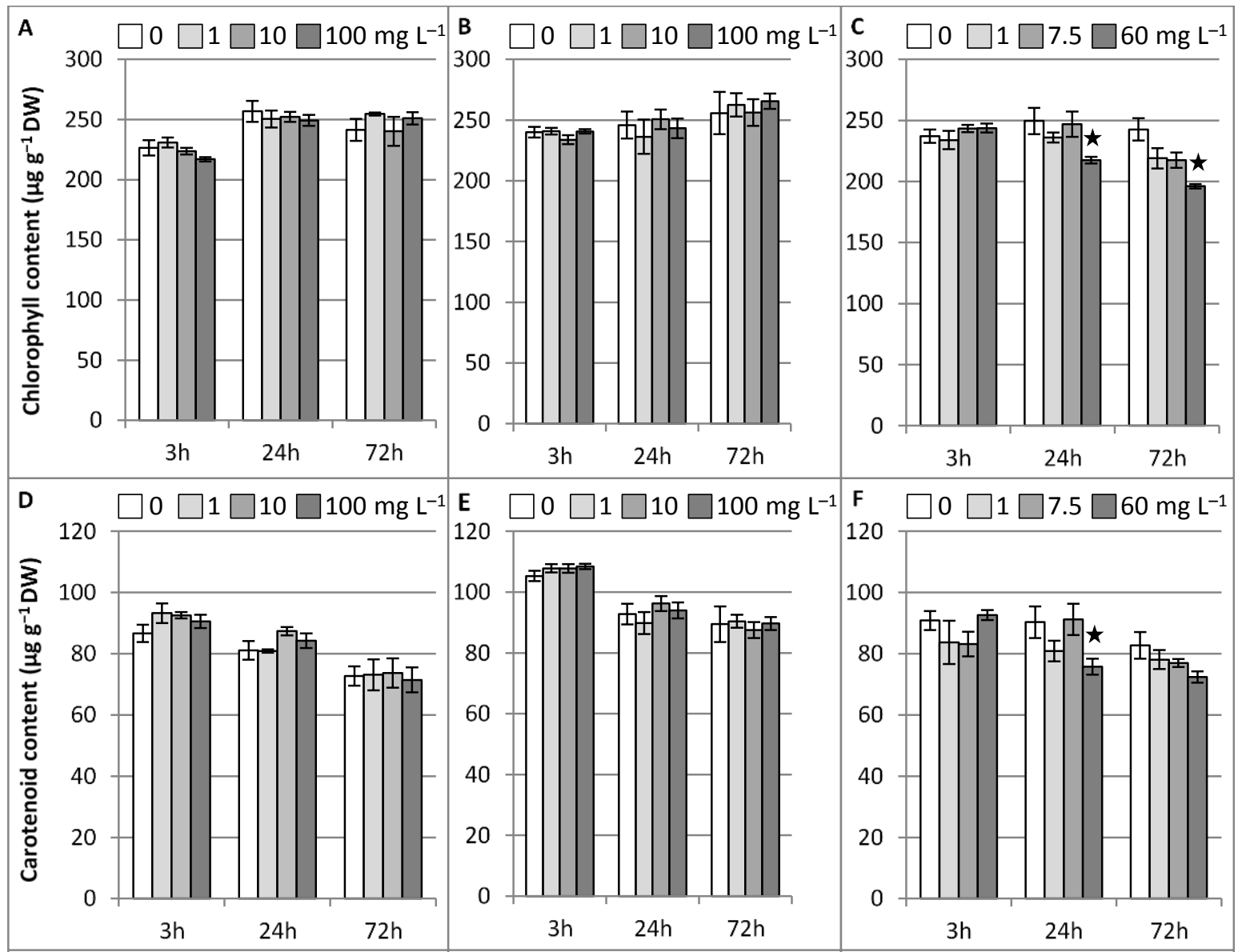

G $\left.\square 0 \square 1 \square 10 \square 100 \mathrm{mg} \mathrm{L}^{-1}{ }_{0,8}^{\text {H }} \square 0 \square 1 \square 10 \square 100 \mathrm{mg} \mathrm{L}^{-1}\right|_{0,6} ^{\mathbf{I}} \square 0 \square 1 \square 7.5 \square 60 \mathrm{mg} \mathrm{L}^{-1}$

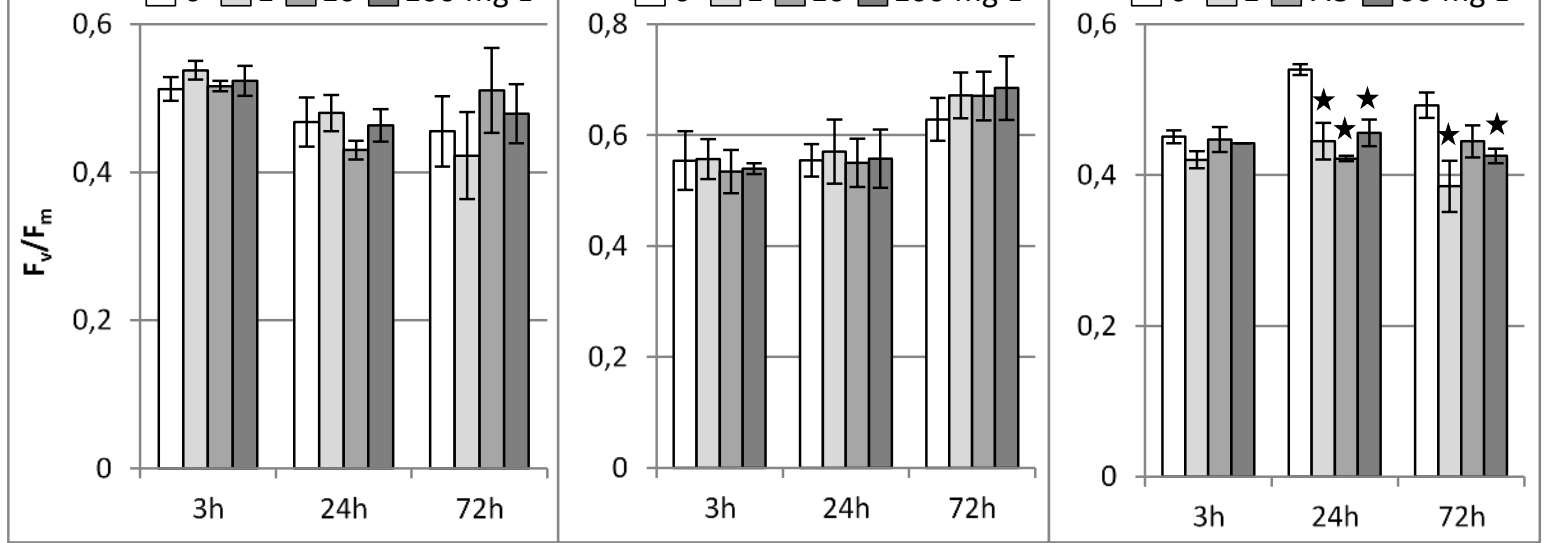


Figure 3

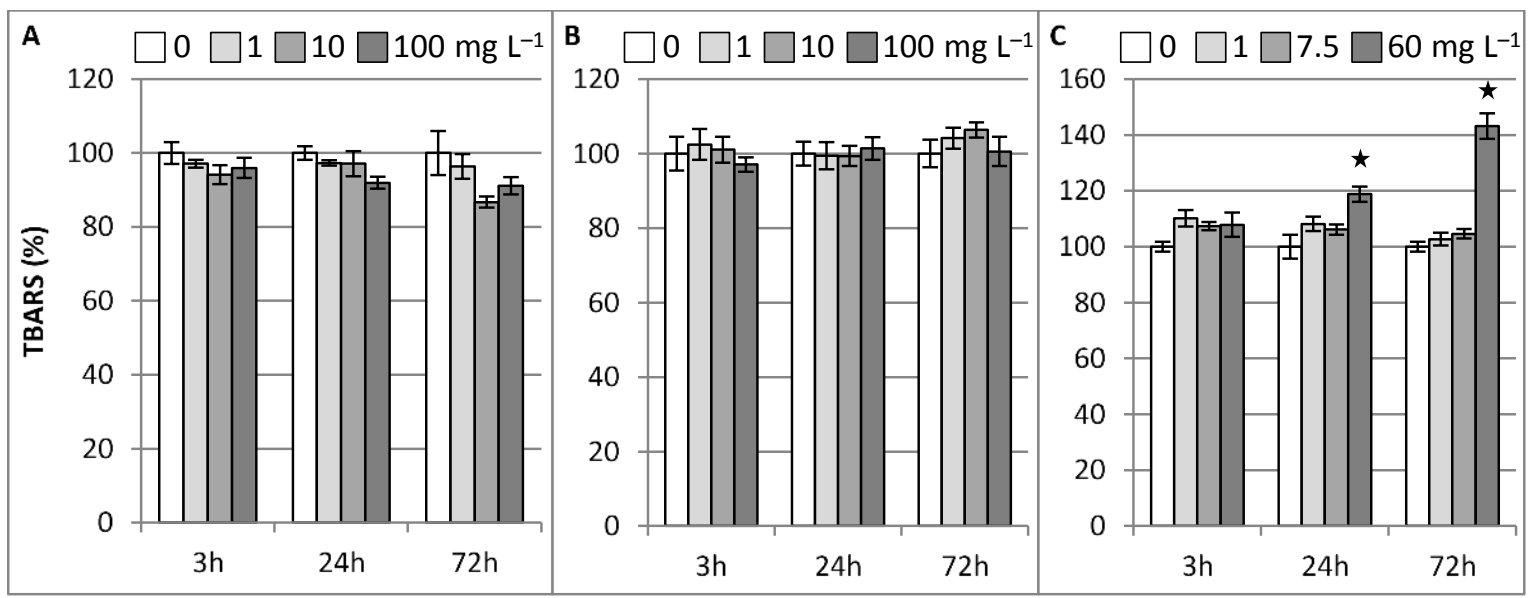



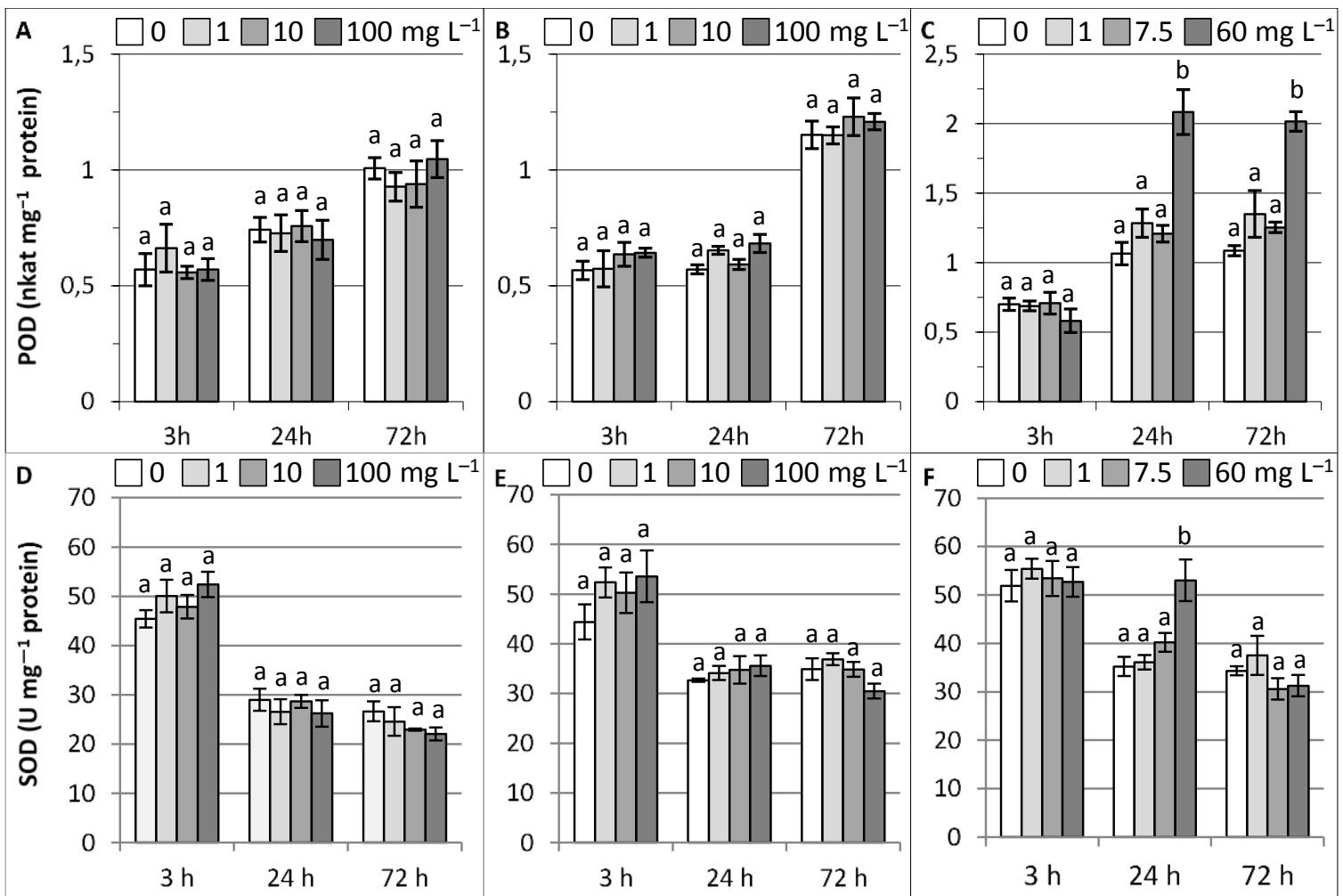

G $\square$. $\left.\square 1 \square 10 \square 100 \mathrm{mg} \mathrm{L}^{-1} \mathrm{H}_{0,3} \square 0 \square 1 \square 10 \square 100 \mathrm{mg} \mathrm{L}^{-1}\right|_{0,3} \square 0 \square 1 \square 7.5 \square 60 \mathrm{mg} \mathrm{L}^{-1}$
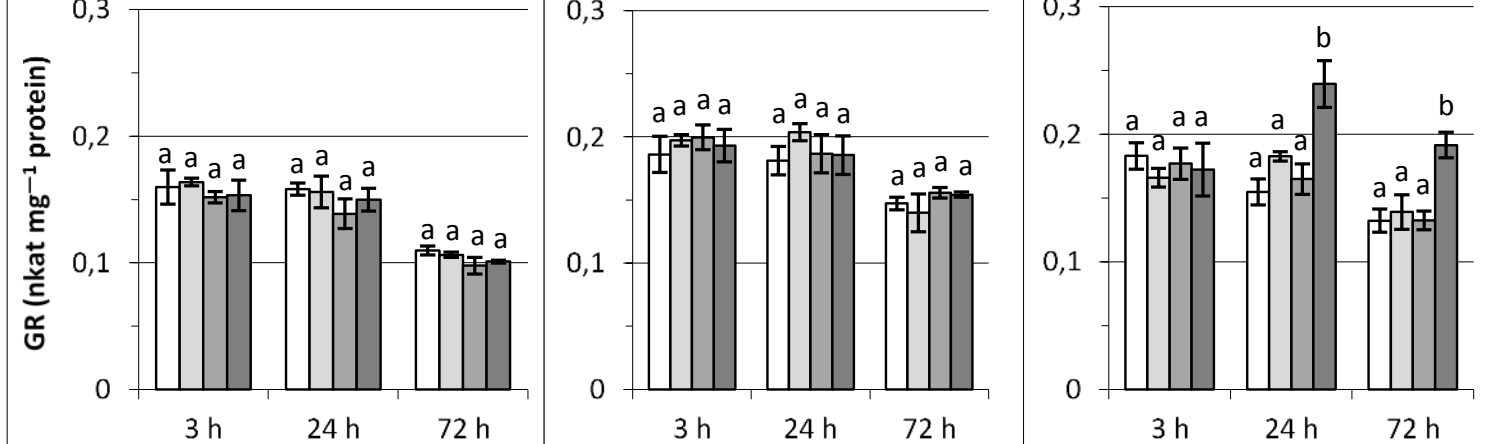

J $\square 0 \square 1 \square 10 \square 100 \mathrm{mg} \mathrm{L}^{-1} \mathrm{~K} \square 0 \square 1 \square 10 \square 100 \mathrm{mg} \mathrm{L}^{-1} \mathrm{~L}_{1} \square 0 \square 1 \square 7.5 \square 60 \mathrm{mg} \mathrm{L}^{-1}$
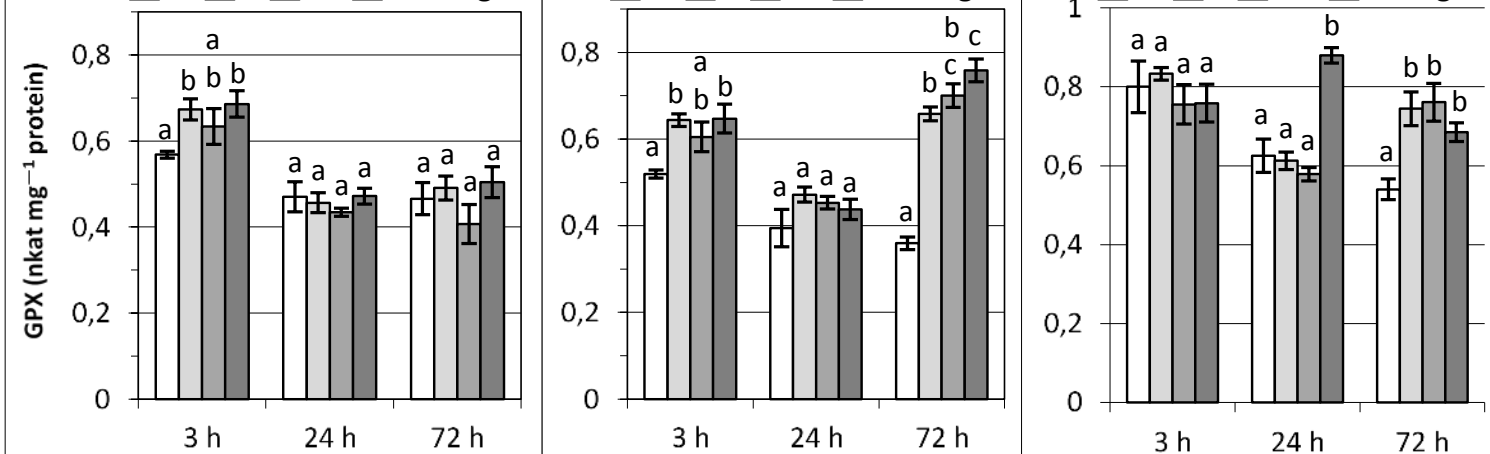

M $\square 0 \square 1 \square 10 \square 100 \mathrm{mg} \mathrm{L}^{-1} \mathbf{N} \square 0 \square 1 \square 10 \square 100 \mathrm{mg} \mathrm{L}^{-1}$ o $\square 0 \square 1 \square 7.5 \square 60 \mathrm{mg} \mathrm{L}^{-1}$
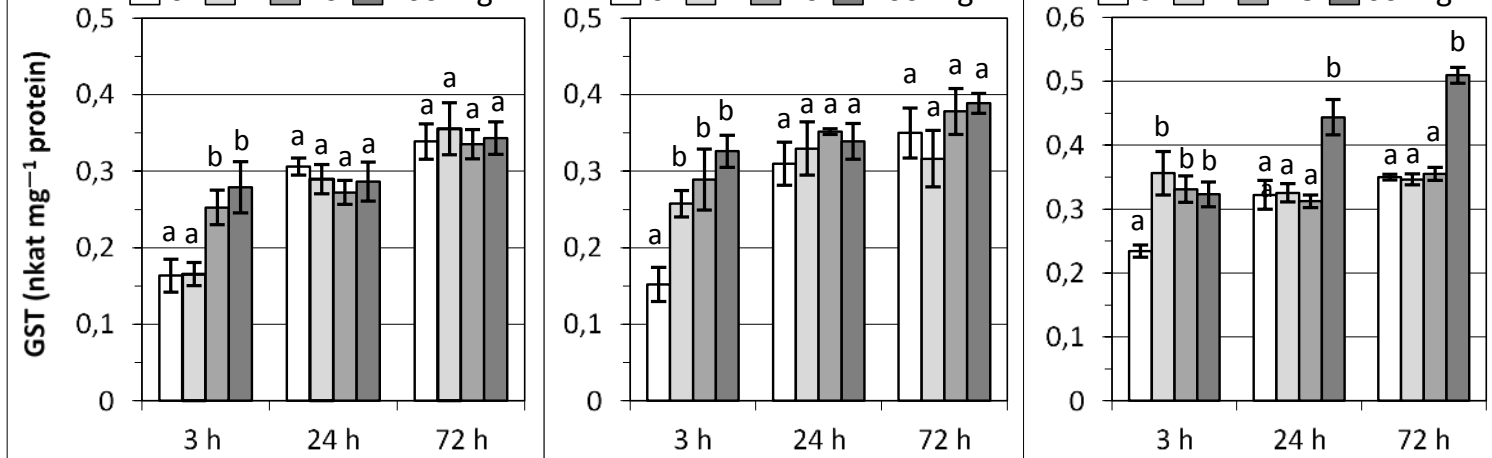

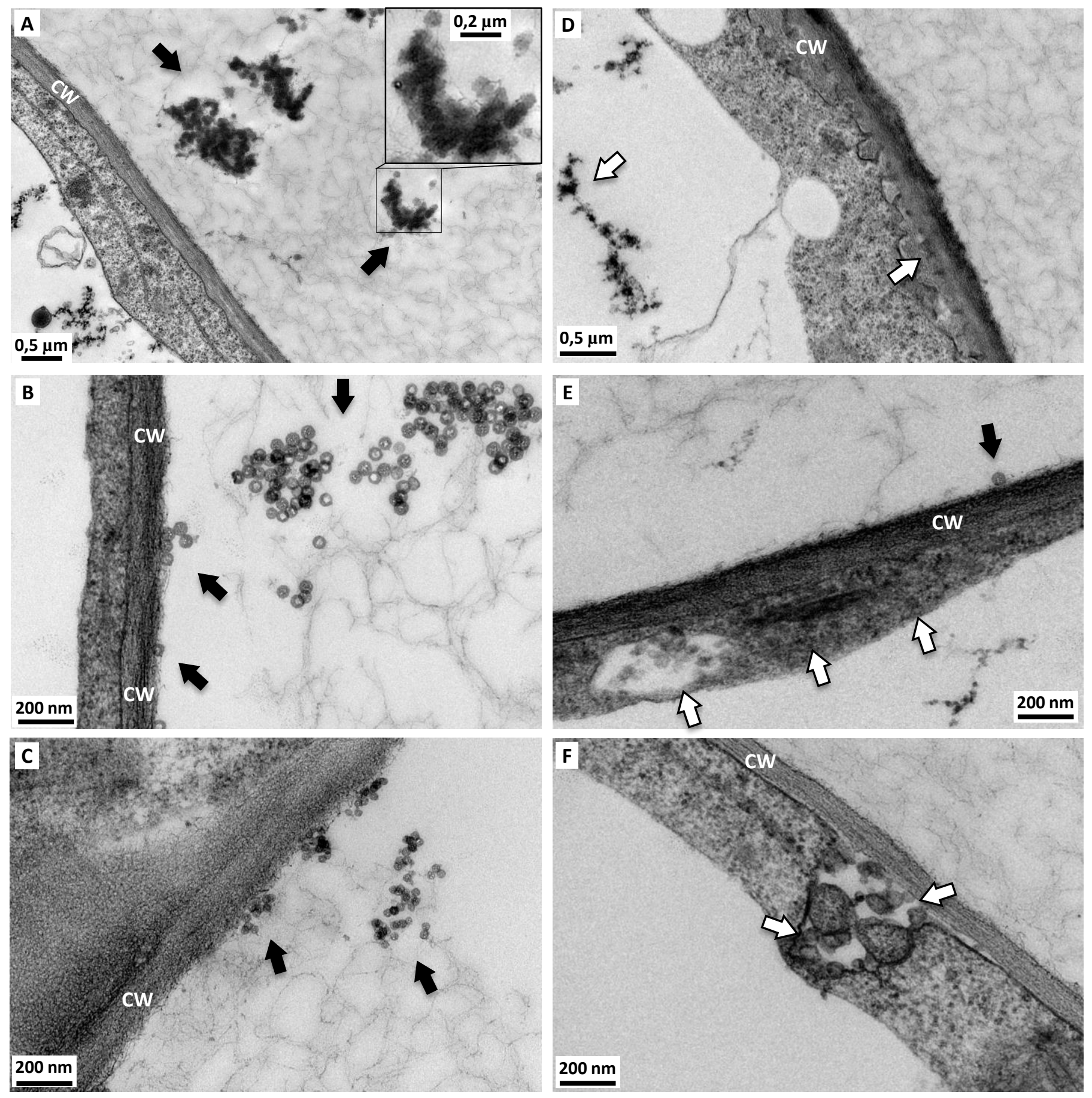

Fig. 5 